\title{
Corrosion Inhibition of Mild-Steel in (1M) HCl using Spands Reagent
}

\author{
Ala a. A. Hussain
}

Chemistry department, College of Education for Pure Sciences - Basrah University alaa.1984hussain@gmail.com

\section{ABSTRACT}

The effect of Spands Reagent on the dissolution of Mild-steel in $1 \mathrm{M} \mathrm{HCl}$ solution was studied using weight loss and galvanostatic polarization techniques. The inhibition efficiency of inhibitor increases with concentration to attain (75.26\%) at concentration $1 \times 10^{-2} \mathrm{M}$, and standing time for $180 \mathrm{~min}$ at $25^{\circ} \mathrm{C}$. Temperature effect on the corrosion behavior was studied at temperature range from $25-45^{\circ} \mathrm{C}$, the results showed that inhibition efficiency decreased with increasing temperature to attain $(64.53 \%)$ at concentration $1 \times 10^{-2} \mathrm{M}$ at $45^{\circ} \mathrm{C}$ and with standing time equal to $180 \mathrm{~min}$. The effect of temperature on the rate of corrosion in the absence and presence of Spands Reagent was also studied. The Kinetic Parameters were calculated and discussed. The polarization curves revealed that the studied inhib itor represent a mixedtype inhibitors. Adsorption of inhibitor was isotherm physisorption type.

\section{Keywords: Corrosion, weight loss, galvanostatic polarization, Spands Reagent, Kinetic Parameters.}

\section{INTRODUCTION}

Acid solution are commonly used for removed of undesirable scale and rust in metal finishing industries, cleaning of boilers, and heat exchangers. Among these, hydrochloric acid is one of the most widelyused agents in the process of acid pickling. Use of inhibitors is one of the most practical methods for protection against corrosion es pecially in acid solution to prevent unexpected metal dissolution and acid consumption[1]. A Mild- steel has been used widely in industry as material for reaction vessels, storage, tanks, etc. However, corrosion damage to mild steel causes heavy losses on the economy and potential problems in safety in work place[2,3].

Azo compound have attracted considerable attention due to their impressive and useful chemical and physical properties [4,5]. A part from their purely chem ical interest, azo ligands have also received special attention because of their mixed soft-hard donor characters $(\mathrm{O}, \mathrm{N}$ and $\mathrm{S}$ donor sites), versatile coordination behavior[6] pharmacological properties [7,8] and optical and thermal properties [9].

The aim of the present work is to study the inhibitive action of Spands Reagent toward the corrosion of Mild-steel in $1 \mathrm{M}$ hydrochloric acid using weight loss and galvanostatic polarization techniques. Moreover, the effect of temperature on the dissolution Mild-steel, as well as, on the inhibition efficiency of the studied compound was also investigated. The following Fig1 represent the structure of Spands Reagent 2-(p-sulphophenyl azo)-1,8-dihdroxynaphthalene-3,6-disulphonic acid trisodium salt

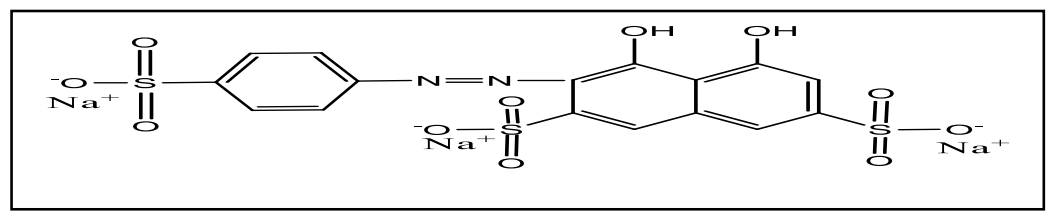

Fig1: The structure of Spands Reagent

\section{Experimental method}

The Mild-steel sample used coupons of with dimension of $3^{\star} 2{ }^{*} 0.5 \mathrm{~cm}$ were used for weight loss measurements. For galvanostatic studies a cylinder rod embedded in araldite with an expose surface area of $\left(1 \mathrm{~cm}^{2}\right)$ was used. The electrode surface was polished with different grades of emery paper, degreased with acetone, and rinsed with distilled water. (1 M) A.R grade hydrochloric acid was used for preparing the corrosive solution. For weight loss experiments, the cleaned Mildsteel coupons were weighed before and after immersion in $25 \mathrm{ml}$ of the test solution for a period of time $180 \mathrm{~min}$. The weight loss for experiments was expressed in (gm). Galvanostatic polarization studies were carried out using Bank EIEIKTRONKIK INTELLGENT CONTROLS Model M Lab 200-Chemistry Department-College of Education for pure Sciences-Basrah University, for calculation of electrochemical parameters three compartment cell with a saturated calomel electrode (Reference electrode), platinum for auxiliary electrode and working electrode was used.

\section{Results and Discussion}

\section{1.Weight Loss Measurements}

The percentage of inhibition efficiency \% IE and surface coverage parameter $\left(\theta\right.$ ) and corrosion rate $\mathrm{R}_{\text {corr }}$ were determined by using following equation[10]:

$\% \mathrm{IE}=\left[1-\frac{\text { Wadd }}{\text { Wfree }}\right] \times 100$ 
$\theta=\left[1-\frac{\text { Wadd }}{\text { Wfree }}\right.$ ]

Where $W_{\text {free }}$ and $W_{\text {add }}$ are the weight losses of Mild-steel in absence and presence of inhibitors respectively.

$$
\mathrm{R}_{\mathrm{corr}}=\frac{\mathrm{W} * \mathrm{~K}}{\mathrm{~A} * \mathrm{D} * \mathrm{t}}
$$

Where $\mathrm{W}$ : is the weight losses of metal(gram), $\mathrm{K}$ : constant $\left(534^{*} 10^{5}\right), \mathrm{A}$ : sample area (inch $\left.{ }^{2}\right), \mathrm{D}: \mathrm{metal}$ density $\left(\mathrm{g} / \mathrm{cm}^{3}\right)$ and t: exposed time (hr).

The results of the measurements are shown in Tables 1 for the corrosion of Mild-steel in $1 \mathrm{M} \mathrm{HCl}$ in the absence and in the presence of different concentrations of Spands Reagent at the temperature of $25^{\circ} \mathrm{C}$. Fig2 represent the variation of the inhibition efficiency \%IE as function of the time (180 min). The inhibition efficiency increased with increasing the inhibitor concentration.

Table 1: Effect of Spands Reagent on Dissolution Mild steel in $1 \mathrm{M} \mathrm{HCl}$

\begin{tabular}{|c|c|c|c|c|c|}
\hline Conc. (M) & $\begin{array}{l}\text { Time } \\
\text { (Min) }\end{array}$ & $\begin{array}{l}\text { Wt-loss } \\
\text { (gm) }\end{array}$ & $\begin{array}{l}\text { Corr. } \\
\text { (mpy) }\end{array}$ & $\% \mathrm{dE}$ & $\theta$ \\
\hline \multirow{6}{*}{0} & 30 & 0.0024 & 123.82 & - & - \\
\hline & 60 & 0.0032 & 82.51 & - & - \\
\hline & 90 & 0.0055 & 94.55 & - & - \\
\hline & 120 & 0.0063 & 81.22 & - & - \\
\hline & 150 & 0.0073 & 75.29 & - & - \\
\hline & 180 & 0.0093 & 79.93 & - & - \\
\hline \multirow{6}{*}{$\times 10^{-4}$} & 30 & 0.0011 & 56.75 & 54.16 & 0.5416 \\
\hline & 60 & 0.0014 & 36.09 & 56.25 & 0.5625 \\
\hline & 90 & 0.0022 & 37.82 & 60.00 & 0.6000 \\
\hline & 120 & 0.0025 & 32.23 & 60.31 & 0.6031 \\
\hline & 150 & 0.0028 & 28.88 & 61.64 & 0.6164 \\
\hline & 180 & 0.0034 & 29.22 & 63.44 & 0.6344 \\
\hline \multirow{6}{*}{$1^{\times 10^{-3}}$} & 30 & 0.0010 & 51.59 & 58.33 & 0.5833 \\
\hline & 60 & 0.0012 & 30.94 & 62.50 & 0.6250 \\
\hline & 90 & 0.0020 & 34.38 & 63.63 & 0.6363 \\
\hline & 120 & 0.0023 & 29.65 & 63.49 & 0.6349 \\
\hline & 150 & 0.0025 & 25.78 & 65.75 & 0.6575 \\
\hline & 180 & 0.0031 & 26.64 & 66.66 & 0.6666 \\
\hline \multirow{6}{*}{$1 \times 10^{-2}$} & 30 & 0.0007 & 36.11 & 70.83 & 0.7083 \\
\hline & 60 & 0.0009 & 23.20 & 71.87 & 0.7187 \\
\hline & 90 & 0.0015 & 25.78 & 72.72 & 0.7272 \\
\hline & 120 & 0.0017 & 21.91 & 73.01 & 0.7301 \\
\hline & 150 & 0.0019 & 19.59 & 73.97 & 0.7397 \\
\hline & 180 & 0.0023 & 19.76 & 75.26 & 0.7526 \\
\hline
\end{tabular}




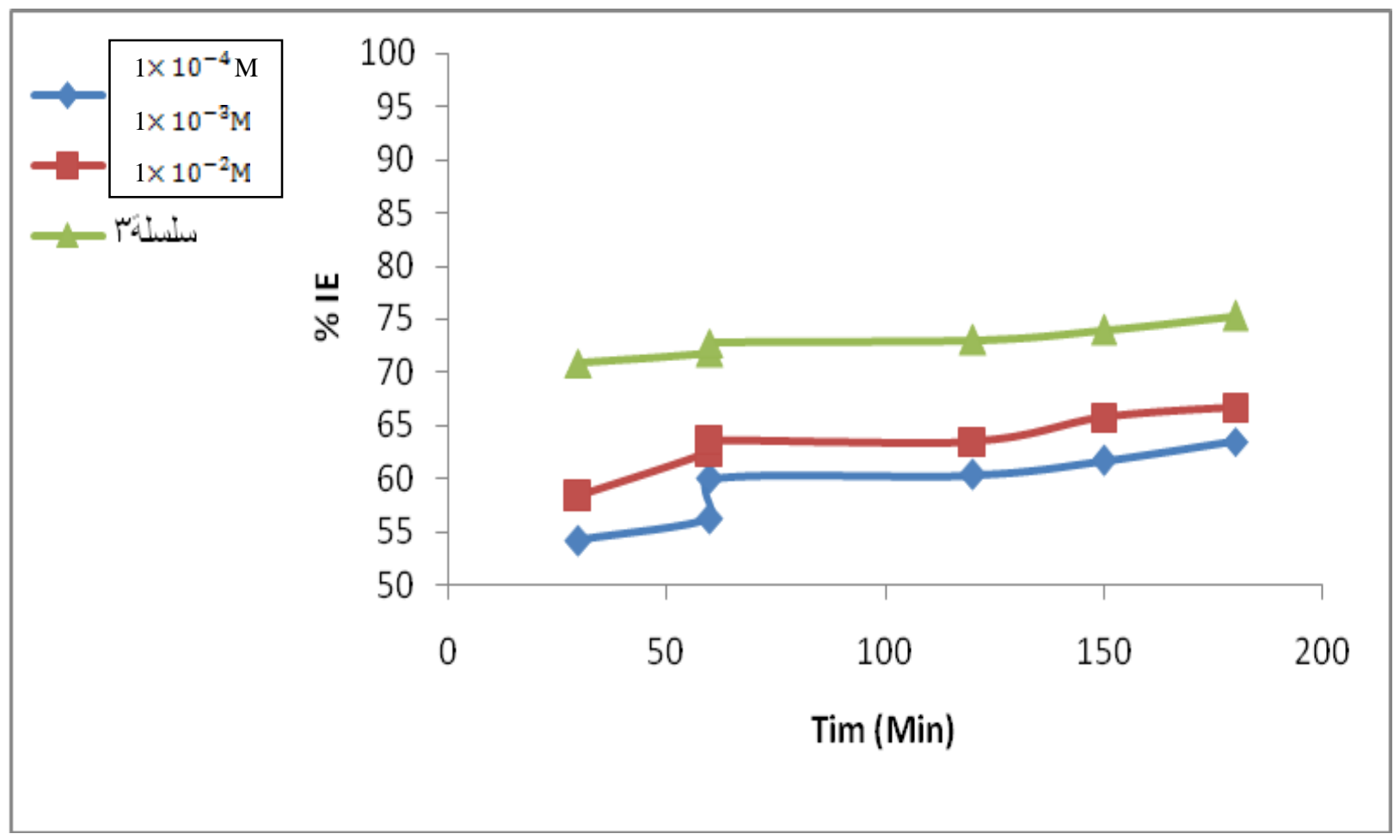

Fig2: Variation of the Inhibition Efficiency \%E as a function of the time in the presence of different concentrations of Spands Reagent at $25^{\circ} \mathrm{C}$ in $1 \mathrm{M} \mathrm{HCl}$

\section{1. 2.Effect of Temperature}

The influence of temperature on the behavior of Mild-steel/acid added of Spands Reagent at various concentrations is investigated by weight loss trends in the temperature range $25-45^{\circ} \mathrm{C}$ during $180 \mathrm{~min}$ of immersion. The variation of the inhibition efficiency of Spands Reagent with temperature is decreased with increasing temperature is suggestive physisorption mechanism which is effectively enhanced with increasing temperature[11]. The results of these measurements are shown in Tables2. Figs 3 represent the variation of the inhibition efficiency \% IE as a function of the temperature .

Table 2: Effect of Spands Reagent on the dissolution Mild steel in $1 \mathrm{M} \mathrm{HCl}$ in the different temperature

\begin{tabular}{|c|c|c|c|c|c|}
\hline Conc. (M) & $\begin{array}{l}\text { Temp } \\
\left({ }^{\circ} \mathrm{C}\right)\end{array}$ & $\begin{array}{l}\text { Wt-loss } \\
\text { (gm) }\end{array}$ & $\begin{array}{ll}\text { Corr. } & \text { Rate } \\
\text { (mpy) } & \end{array}$ & $\% \mathrm{dE}$ & $\boldsymbol{\theta}$ \\
\hline \multirow{3}{*}{0} & 25 & 0.0093 & 79.93 & - & - \\
\hline & 35 & 0.0123 & 105.71 & - & - \\
\hline & 45 & 0.0141 & 121.18 & - & - \\
\hline \multirow{3}{*}{$1^{\times 10^{-4}}$} & 25 & 0.0034 & 29.22 & 63.44 & 0.6344 \\
\hline & 35 & 0.0050 & 42.97 & 59.34 & 0.5934 \\
\hline & 45 & 0.0061 & 52.42 & 56.73 & 0.5673 \\
\hline \multirow{3}{*}{$1^{\times 10^{-3}}$} & 25 & 0.0031 & 26.64 & 66.66 & 0.6666 \\
\hline & 35 & 0.0048 & 41.25 & 60.97 & 0.6097 \\
\hline & 45 & 0.0058 & 49.85 & 58.86 & 0.5886 \\
\hline \multirow{3}{*}{$1^{\times 10^{-2}}$} & 25 & 0.0023 & 19.76 & 75.26 & 0.7526 \\
\hline & 35 & 0.0038 & 32.66 & 69.10 & 0.6910 \\
\hline & 45 & 0.0050 & 43.83 & 64.53 & 0.6453 \\
\hline
\end{tabular}




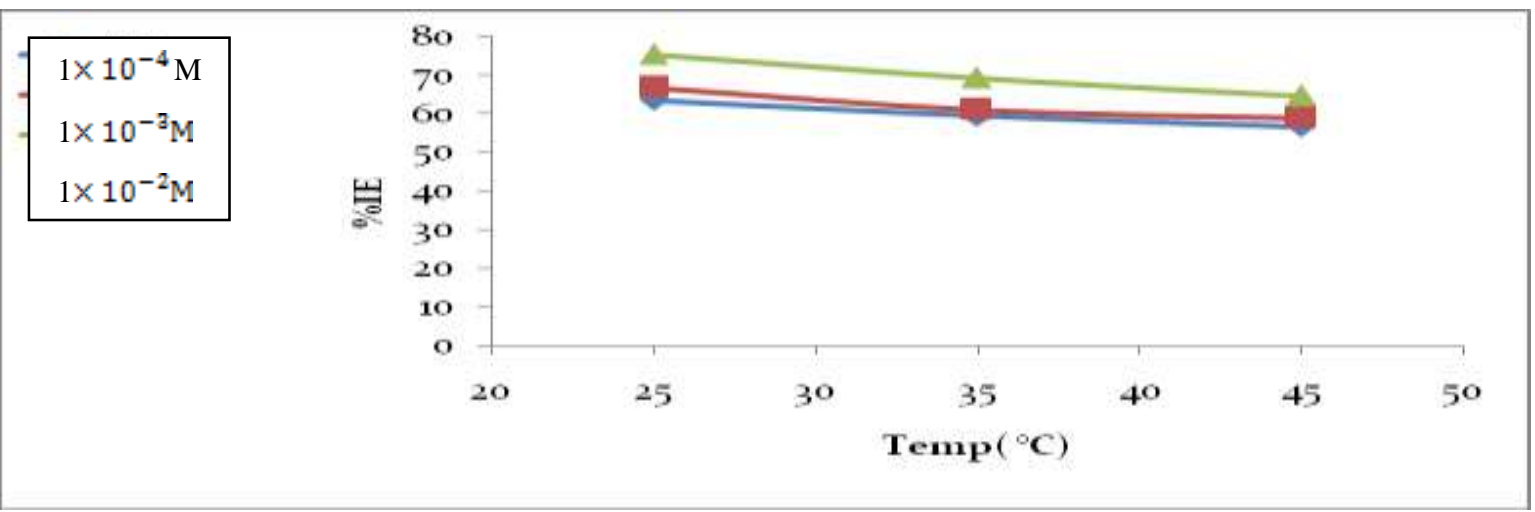

Fig3: Variation of the Inhibition Efficiency $\% \mathrm{dE}$ as a function of the temperature in the presence of different concentrations of Spands Reagent in $1 \mathrm{M} \mathrm{HCl}$

\section{2 Kinetic Parameters}

In order to obtain the effect of inhibitors on the kinetic parameters, gravimetric weight loss experiment were conducted at 25,35 and $45^{\circ} \mathrm{C}$ in $1 \mathrm{M} \mathrm{HCl}$ after 180 min of immersion in the absence and presence of Spands Reagent. The activation energy Ea of corrosion process was calculated using the following equation[12]:

$\ln \left(r_{2} / r_{1}\right)=\left(E a\left(T_{2}-T_{1}\right) / R\left(T_{2}{ }^{*} T_{1}\right)\right.$

Where

$r_{1}=$ corrosion rate at $303 \mathrm{~K}$

$r_{2}=$ corrosion rate at $313 \mathrm{~K}$

$\mathrm{Ea}=$ activation energy

$\mathrm{R}=$ gas constant $\left(8.3143 \mathrm{~J} \cdot \mathrm{K}^{-1} \cdot \mathrm{mol}^{-1}\right)$

$\mathrm{T}_{1}$ and $\mathrm{T}_{2}=$ Absolute temperature $(\mathrm{K})$

Free energy of adsorption $\Delta G$ was calculated using the following equation[13]:

$\Delta \mathrm{G}=-\mathrm{R} \operatorname{T} \ln \left[55.5^{\theta} / \mathrm{C}\left(1-{ }^{\theta}\right)\right]$

Where

$\theta$

$=$ degree of coverage on the metal surface

$\mathrm{C}=$ concentration of inhibitor

$\mathrm{R}=$ gas constant $\left(8.3143 \mathrm{~J} \cdot \mathrm{K}^{-1} \cdot \mathrm{mol}^{-1}\right)$

$\mathrm{T}=$ Absolute temperature $(\mathrm{K})$

And For calculating the entropy $\Delta S$ and enthalpy $\Delta \mathrm{H}$ apply the alternative formulation of the Arrhenius equation is the transition state equation[14]:

Rcorr $\left.=\frac{\frac{R T}{N h}}{\exp \left[{ }^{R}\right.}\right] \exp \left[-\frac{\Delta S}{R T}\right]$

Where

Rcorr= corrosion rate

$\mathrm{R}=$ gas constant $\left(8 \cdot 3143 \mathrm{~J} \cdot \mathrm{K}^{-1} \cdot \mathrm{mol}^{-1}\right)$

$\mathrm{T}=$ temperature $(\mathrm{K})$

$\mathrm{N}=$ Avogadro 's number $\left(6.2^{\times 10^{23}}\right)$

$\mathrm{h}=$ plank 's constant $\left(6.62^{\times 10^{-34}}\right.$ J.S $)$

The results of these measurements are shown in Tables 3. 
Table3 : kinetic parameters of Spands Reagent on the dissolution Mild steel in $1 \mathrm{M} \mathrm{HCl}$

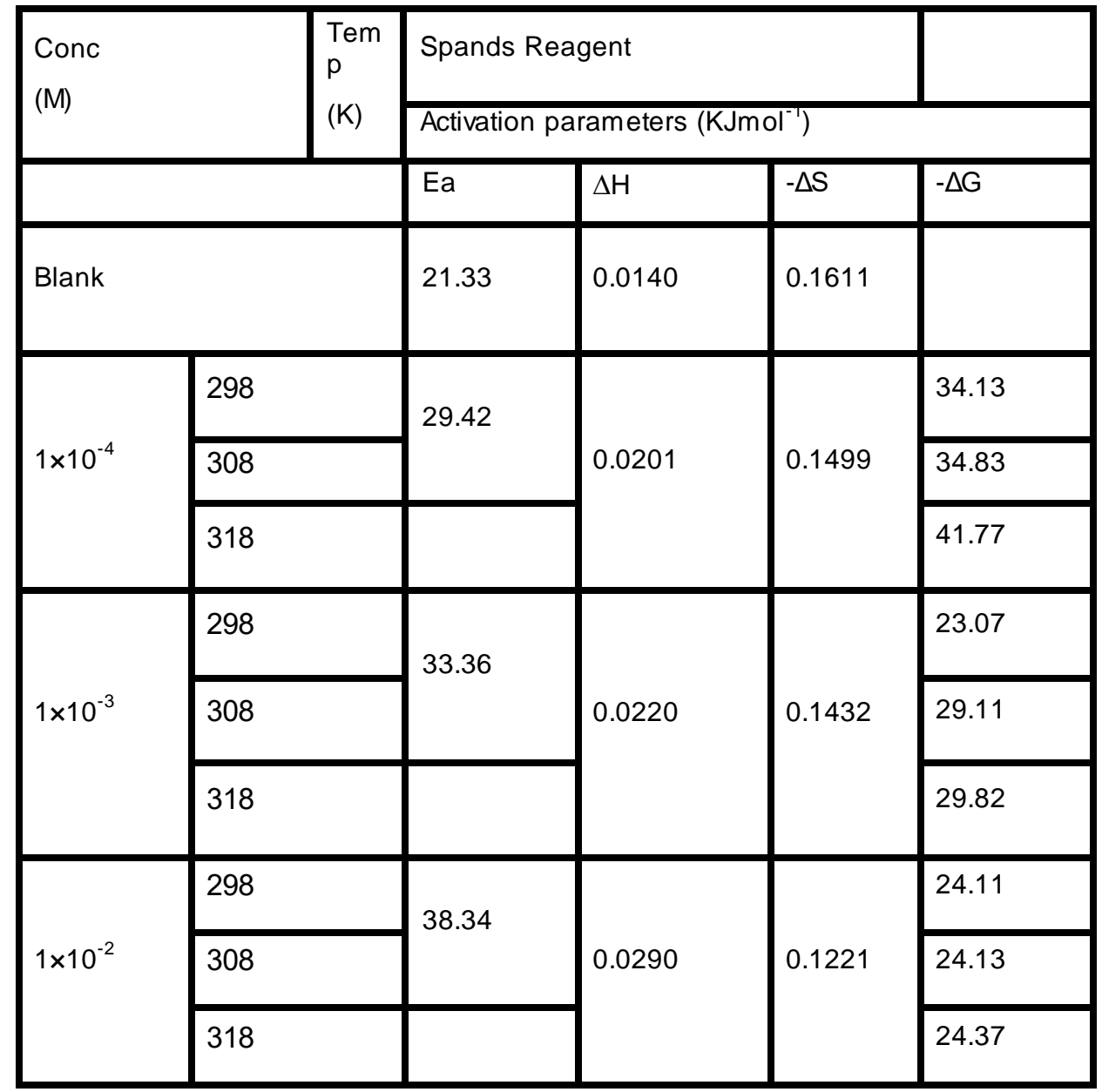

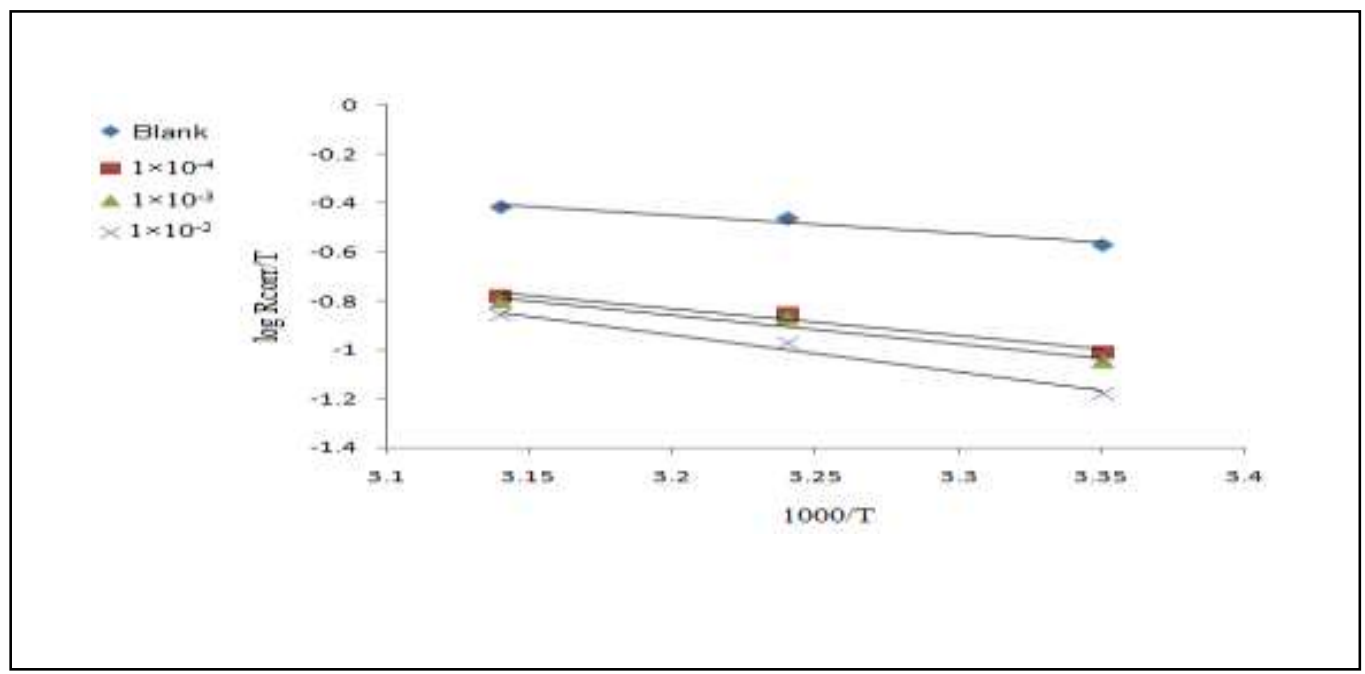

Fig4 : Arrhenius Plots $\log R_{\text {corr }} / \mathrm{T}$ ) vs. 1 T for Mild-steel in Different Additives of Inhibitor Spands Reagent

The values of Ea are give in Table 3 the values of Ea increase in the presence of the inhibitors. This was attributed to an appreciable decrease in the adsorption process of the inhibitor on the metal surface with increase of temperature and corresponding increase in the reaction rate because of greater area of the metal that is exposed to $\mathrm{HCl}$ solution. Fig4: shows Arrhenius Plots Log $R_{\text {corr }} / T$ ) vs $1 / T$. Straight lines are obtained with a slop of $(-\Delta H / 2.303 R$ ) and an intercept of (log $\mathrm{R} / \mathrm{Nh}+\Delta \mathrm{S} / 2.303 \mathrm{R}$ ) from which the values of $\Delta \mathrm{H}$ and $\Delta \mathrm{S}$ are calculated and listed in Table3. 
From inspection of Table (3) it is clear that the positive values of $\Delta \mathrm{H}$ reflect that the process of adsorption of the inhibitors on the Mild-steel surface is an endothermic process. The value of $\Delta S$ in the presence and absence of the inhibitors are negative. This implies that the activation complex is the rate determining step representing association rather than dissociation, indicating that a decrease in disorder takes place on going from reactant to the activated complex[15].

The negative values of $\Delta G$ means that the adsorption of Spands Reagent on Mild-steel surface is a spontaneous process, and furthermore the negative values of $\Delta G$ also show the strong interaction of the inhibitor molecules on to the Mild -steel surface[16].

It was found that $\Delta G$ increases negatively with increasing the temperature. This phenomenon once again indicates that the adsorption is favourable with increasing experimental temperature and dominates on the desorption of the inhibitor from the Mild-steel surface[17].

\section{3. Adsorption Isotherm}

Adsorption isotherms are very important in understand the mechanism of inhibition of corrosion reaction. The most frequently used adsorption is otherm are Frundlich, Langmuir, Frumkin, and Temkin isotherm. The best fitted one follows

Langmuir isotherm. Plotting $\left(\mathrm{C} /{ }^{\theta}\right)$ versus concentration $(\mathrm{C})$ give rise to straight lines as shown in Fig. $5^{*}$ The inhibitor Spands Reagent adsorbs on the Mild-steel surface according to the Langmuir kind isotherm model by the relation[18]: $c^{\theta}=1 / K+C$

Where

$\mathrm{K}=\mathrm{is}$ the equilibrium constant of the adsorption process.

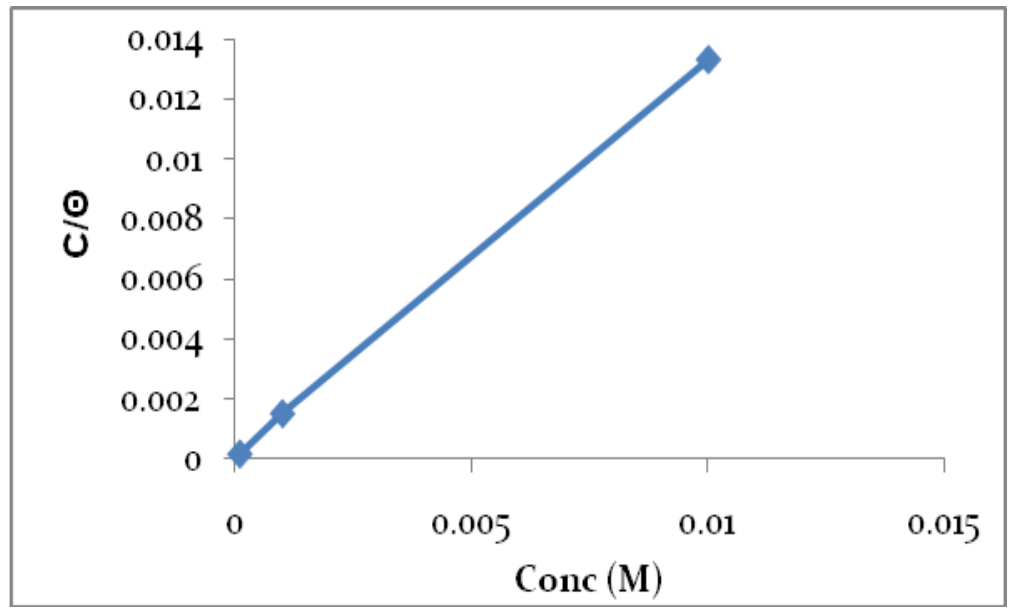

Fig5: Langmuir Adsorption Isotherm Model for Spands Reagent in1M HCI on the Surface of Mild- Steel

\section{4. Polarization Measurements}

Polarization behavior of Mild-steel in $1 \mathrm{M} \mathrm{HCl}$ in the presence and absence of Spands Reagent $25^{\circ} \mathrm{C}$ is shown in Fig.6.lt was found that both anodic and cathodic reaction of Mild-steel electrode corrosion were inhibited with increasing concentration of inhibitor. These results suggest that not only the addition of inhibitor reduce anodic dissolution but als 0 retard the hydrogen evolution reaction.

Electrochemical parameters such as corrosion potential $\left(\mathrm{E}_{\text {corr }}\right)$, corrosion current density $\left(\mathrm{I}_{\text {corr }}\right)$, Cathodic Tafel constant $(\beta c)$ and anodic Tafel constant $(\mathrm{Ba})$ were calculated from Tafel plots. Data in Tables 4 the results of electrochemical parameters. The addition of inhibitor causes a decrease of the current density, the maximum decrease in $I_{\text {corr }}$ was

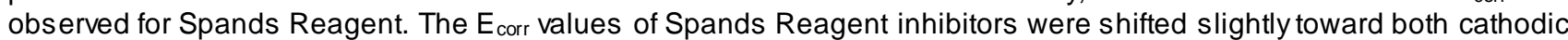
and anodic directions and did not show any definite trend in $1 \mathrm{M} \mathrm{HCl}$. This may be contributed to the mixed -type behavior of the studied inhibitors. Moreover, these inhibitor caused change in the anodic and Cathodic Tafel slope indicating that the inhibitor are affecting the anodic and cathodic reaction mechanism without blocking the reaction sites of Mild-steel surface. Inhibition efficiency (\%IE) was calculated by the relation[19]: $\%$ dE $=\left[1\right.$ - $\left.{ }^{\frac{\text { Ifree }}{\text { Ifree }}}\right] \times 100$

$l_{\text {add }}, I_{\text {free }}$ are the corrosion current in absence and presence of inhibitors. Data in Table 4 shows that the inhibition efficiency increased with increasing the inhibitor concentration, indicating the inhibiting effect of these compounds . 
Table 4 : The Values of corrosion parameters for the corrosion of Mild-steel in $1 \mathrm{M} \mathrm{HCl}$ by galvanostatic polarization in presence (Spands Reagent)

\begin{tabular}{|c|c|c|c|c|c|}
\hline $\begin{array}{c}\text { Conc } \\
(\mathrm{M})\end{array}$ & $\begin{array}{c}\text { Icorr } \\
\mu \mathrm{ACCm}\end{array}$ & $\begin{array}{c}\text { Ecorr } \\
\mathrm{mV}\end{array}$ & $\begin{array}{c}\beta c \\
\mathrm{mV} \cdot \mathrm{dec}^{-1}\end{array}$ & $\begin{array}{c}\beta \mathrm{a} \\
\mathrm{mV} \cdot \mathrm{dec}^{-1}\end{array}$ & $\mathrm{IE}^{\%}$ \\
\hline 0.00 & 210.0 & -420.5 & -111.0 & 98.8 & - \\
\hline $1^{\times 10^{-4}}$ & 70.8 & -448.1 & -120.8 & 68.3 & 66.28 \\
\hline $1^{\times 10^{-3}}$ & 65.9 & -475.3 & -118.5 & 60.9 & 68.61 \\
\hline $1^{\times 10^{-2}}$ & 50.5 & -461.0 & -125.3 & 61.4 & 75.95 \\
\hline
\end{tabular}

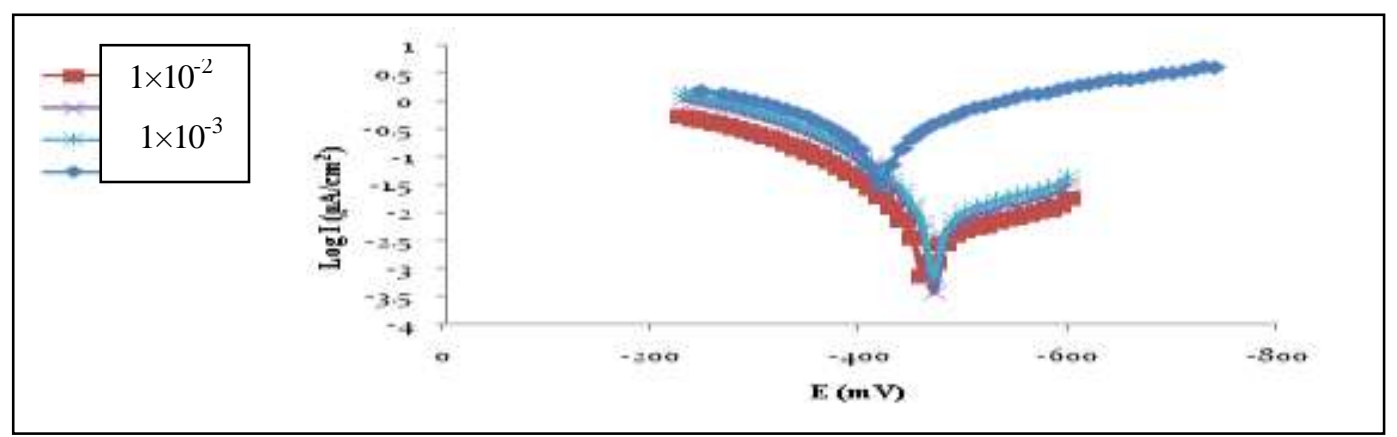

Fig6: Galvano static polarization curves of Mild-steel in 1M HCl in Presence Inhibitor Spands Reagent at $25^{\circ} \mathrm{C}$

\section{5. Mechanism of Inhibition}

From the results obtained from electrochemical and weight loss measurements, it was concluded that the (Spands Reagent) inhibit the corrosion of Mild-steel in $1 \mathrm{M} \mathrm{HCl}$ by adsorption at Mild-steel solution interface. It is general assumption that the adsorption of organic molecules may adsorb on the metal surface in four types, namely[20,21].

1-Electrostatic interaction between the charged molecules and the charged metal.

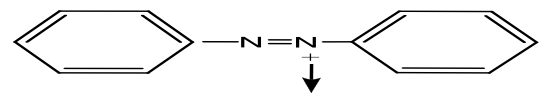

$\mathrm{Fe} \quad \mathrm{Fe} \quad \mathrm{Fe} \quad \mathrm{Fe}$

2- Interaction of unshared electron pairs in the molecule with metal.

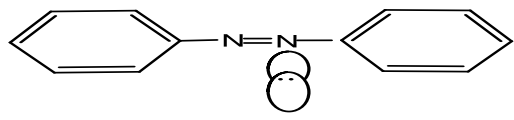

\section{$\mathrm{Fe} \quad \mathrm{Fe} \quad \mathrm{Fe} \quad \mathrm{Fe}$}

3- Interaction of pi-electrons with the metal.

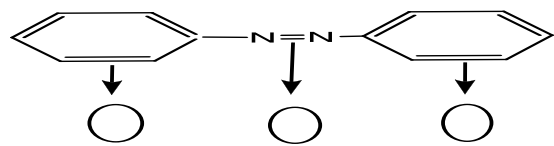

$\mathrm{Fe} \quad \mathrm{Fe} \quad \mathrm{Fe} \quad \mathrm{Fe}$ 
4-A combination of types $(1,3)$.

\section{Conclusions}

The following conclusions could be predict from this study:

1 - The corrosion of Mild-steel in $1 \mathrm{M} \mathrm{HCl}$ is inhibited by the addition of Spands Reagent

2- The inhibition efficiency increases with increases in the concentration of these compounds.

3- The inhibition efficiency of Spands Reagent decreases with the temperature and the activation corrosion energy increases in presence of the inhibitor.

4- The inhibition of corrosion by Spands Reagent is due to physisorption adsorption on the metal surface.

5- Spands Reagent act as mixed type of inhibitors, and obey Langmuir adsorption isotherm .

\section{References}

1- Ashassi-sorkhabi . H, Seifzadeh . D and Hosseini . M. G, Corrosion .Science , $\underline{50}, 3363-3370$ (2008).

2- Migahed . M. A, Abdul- Raheim . A . M, Atta . A . M and Brostow . W, Materials chemistry and physics, 121, 208-214 (2010).

3- Asefi . D, Arami . M and Mahmoodi . N, Corrsion Science, 52, 3586-3598 (2010).

4- Ispir .E, Dye pigment, $\underline{82}, 13$ (2009).

5- Khanmohammadi. H and Darvishpour. M, Journal of Inorganic and Organometallic polymers and Materials, $\underline{21}, 541(2011)$.

6- Dinc. H, aple, Toker . F, Durucasu . I , Avcibas . N, and Icli . I . S, Dye pigment, 75, 11 (2007).

7- Odabas. M, Og Tu, Albayrak . C , Özkanca . R, Aykan . F . Z and Lonecke . P, Journal of Molecular structure, $\underline{71}$, 840 (2007).

8- Zhang . D, Zang . M , Liu . Z, Xu . M, Li . F, Yi . T and Huang . C, Tetrahedron Lett, 47, 7093 (2006).

9-Pattanyak. P, Pratihar. J . L, Patra . D, Uranik. V. G and Chatto-padhyay .S, Polyhedron, 27, 2209 (2008).

10- Kadim . M . Y, Abdulsada . A . M and Alshawi J . M . S, Journal of Basrah Researches ((Sciences)), 40(3), 108127(2014).

11- Abdallah . M, Fouda . A . S, Shama . S . A and Afifi . E . A, African Journal of Pure and Applied Chemistry, 2(9), 083-091 (2008).

12- Eddy. N .O and Odoemelam . S . A, African Journal of Pure and Applied Chemistry, 2, 132 (2008).

13- Hosseini . S . M. A, Azimi . A, Sheikhshoaei . I and Salari . M, Journal of Iranian chemical Society, $\underline{7}, 799-806$ (2010).

14- Noor . E . A and Al. Moubaraki . A . H, Materials chemistry and physics, 110,145-154 (2008).

15- Al-Juaid . S . S, Portugaliae ElectrochimicaActa, 25, 363-373 (2007).

16- Elachouir . M, Hajji . M . S, Salem . M, Kertit . S, Aride . J, Coudert . R and Essassi . E, Corrosion, $\underline{52}, 103,(1996)$.

17- Savitri . B . V and Mayanna . S, Indian Journal of chemical Technology, $\underline{3}, 256,(1996)$.

18- Langmuir . I and Amer. J, chemical Society, $\underline{39}, 1848$ (1947).

19- Zaafarany . I. A, International Journal of Corrosion and Scale Inhibition , 3(1), 12-27 (2014).

20- Li .X. H, Deng . S . D, Fu . H and Mu . G . N, Journal Applied Electrochem, 39.1125 (2009).

21- Lowmunkhong . P, Vngthararak . D and Sutthivaiyakit . P, Corrosion Science, 52 , 30 (2010). 